\title{
Comparative Cost Benefit Analysis of Conventional Farming and Agroecological Farming for Paddy Cultivation in Bachok, Kelantan
}

\author{
Ah Choy Er, Habibah Ahmad, and Azima Abdul Manaf
}

\begin{abstract}
In Malaysia, conventional rice farming is the predominant method of rice cultivation with attendant problems like the harmful effects of the utilisation of synthetic pesticides and synthetic fertilisers. Thus, conventional rice farming was compared to the System of Rice Intensification (SRI) method, a variant of agroecological rice farming, in Kampung Klerek, Bachok District, and Kelantan. It must be noted that the agroecological rice farming method is the farmer's maiden attempt. Agroecological rice farming is a much more environmentally friendly approach. The aim of this paper is to compare conventional rice farming vis-à-vis agroecological rice farming from a financial perspective. Comparative Cost Benefit Analysis has been adopted to determine which the better alternative is. However, the results go beyond financial consideration as conventional rice farming is chemically driven whereas agroecological rice farming is grounded on environmentalism. The results indicated that agroecological rice farming is a better financial alternative with higher revenue and lower cost of production. The higher revenue is due to higher production yield whereas the lower cost of production is due to contributory factors like lower labour cost, lower seed utilisation and ancillary cost, zero cost for synthetic fertilisers and lower fuel and ancillary cost for machinery despite higher organic fertiliser cost. Thus, on a long-term basis, with the effect of the learning and experience curve, the cost of production can be lowered further. Moreover, the higher rice yield, less seed wastage, utilisation of organic fertilisers, organic pesticides and natural pest control methods are in sync with good environmental practices.
\end{abstract}

Index Terms-Agroecological rice farming, comparative cost-benefit analysis, conventional rice farming, and fertilisers.

\section{INTRODUCTION}

Conventional rice farming is the predominant method of rice cultivation in Malaysia. Likewise, this farming method is also predominant in the eight granary areas, of which Bachok is in the Kemubu granary. These granary areas have a major irrigation infrastructure that allows for multiple cropping. Over the years new farming practices, including mechanisation, were introduced to reduce labour dependency. Manual transplanting of seeds has switched to direct seeding via broadcasting of seeds to wet soil. Improved rice varieties like MRQ76, a fragrant rice, were introduced due to its high yielding and less disease prone characteristics [1]. In addition,

Manuscript received December 12, 2020, revised March 18, 2021. This work was supported by the Universiti Kebangsaan Grand Challenge Grant (DCP-2017-004/4) under the leadership of Prof. Dr. Er Ah Choy.

The authors are with Universiti Kebangsaan Malaysia, Bangi, Malaysia (corresponding author: Ah Choy Er; email: eveer@ukm.edu.my, ha@ukm.edu.my, azima@ukm.edu.my). as it is a fragrant rice, it is also in a position to command a premium price. In a move to boost rice productivity, increasing use of pesticides, herbicides and fertilisers occurred to boost yield.

The introduction of mechanisation not only helps boost productivity but also aids in the reduction of labour dependency [2]. Tractors are used for tilling whereas mechanical equipment is widely used for spraying synthetic pesticides and also for spraying and mist blowing of fertilisers [3]. However, the use of synthetic pesticides and inorganic fertilisers has an impact on the environment and human health. Studies in Malaysia and in other parts of the world indicated the harmful effects of synthetic pesticides, synthetic herbicides and inorganic fertilisers on human health and the environment [4]-[8]. Thus, the search for a more environmentally-friendly approach to rice cultivation has been an on-going process.

A more sustainable form of rice farming like System of Rice Intensification (SRI), a variant of agroecological rice farming and also organic rice farming, was adopted. The SRI method of farming is in consonance with the UN 2030 Agenda for Sustainable Development [9]. This Agenda focuses on poverty eradication as indispensable requirement for Sustainable Development (SD). Conventional rice farming is based on intensive industrial-scale agricultural practices with high external inputs comprising of chemical fertilisers, pesticides, mechanical ploughing and genetic engineering technology. SRI, an agroecological method, reduces water requirements, increase in land productivity, less reliance on artificial fertilisers, pesticides, herbicides and other agro-chemicals as well as mitigating climate change and greenhouse gases reduction [10]. In addition, it also harms the health of producers and also consumers too. Thus, SRI contributes in meeting the many goals and challenges of the SD agenda. However, the adoption was on a sporadic basis with not many farmers having working knowledge on it. Being agroecological, it is much more environmentally friendly and supportive of human health [11]. The farming practices would be different where there is lesser tillage requirement and higher dependence on organic matters like organic fertilisers and organic pesticides [12].

A comparison between the key SRI practices and standard methods for irrigated rice farming are highlighted in Table I. The standard practices are akin to conventional rice farming.

Thus, the aim of this study is to compare conventional rice farming vis-a-vis agroecological rice farming from a financial perspective, at Kampung Klerek, Bachok, taking into consideration the different farming practices adopted in both types of farming. Different farming practices have 
different yields as well as different inputs utilised and associated different input costs. This, in itself, will also have an impact on the environment. Thus, the financial consideration also encompasses the farming practices of conventional rice farming which is chemically driven whereas agroecological rice farming is grounded on environmentalism.

TABLE I: KEY SRI VERSUS STANDARD PRACTICES FOR IRRIGATED RICE CULTIVATION

\begin{tabular}{lll}
\hline $\begin{array}{l}\text { Cultivation } \\
\text { Practices }\end{array}$ & Standard Methods & SRI Methods \\
\hline $\begin{array}{l}\text { Seed Selection and } \\
\text { Preparation }\end{array}$ & $\begin{array}{l}\text { Seeds are not selected } \\
\text { or treated. }\end{array}$ & $\begin{array}{l}\text { Seeds are soaked for 24 } \\
\text { hours prior to seeding to } \\
\text { eliminate non-viable } \\
\text { seeds }\end{array}$ \\
\hline $\begin{array}{l}\text { Nursery } \\
\text { management }\end{array}$ & $\begin{array}{l}\text { Flooded nurseries, } \\
\text { densely seeded. }\end{array}$ & $\begin{array}{l}\text { Non-flooded nurseries, } \\
\text { often raised beds, } \\
\text { non-densely seeded. }\end{array}$ \\
\hline $\begin{array}{l}\text { Age of seedlings } \\
\text { when planted }\end{array}$ & $\begin{array}{l}21-30 \text { days, sometimes } \\
\text { up to 60 days. }\end{array}$ & $\begin{array}{l}8-12 \text { days, representing } \\
\text { the 2-leaf stage. }\end{array}$ \\
\hline Spacing & $\begin{array}{l}\text { Hills are 10-15 cm } \\
\text { apart, in rows or } \\
\text { random spacing. }\end{array}$ & $\begin{array}{l}\text { Hills in square pattern, } \\
\text { with spacing 25X25cm or } \\
\text { more. }\end{array}$ \\
\hline $\begin{array}{l}\text { Number } \\
\text { plants/hills }\end{array}$ & $\begin{array}{l}3-5 \text { plants/hill; } \\
130-500 \text { plants per }{ }^{2} .\end{array}$ & $\begin{array}{l}1 \text { plant/hill }(<16 \text { plants per } \\
\left.\mathrm{m}^{2}\right) .\end{array}$ \\
\hline Water management & $\begin{array}{l}\text { Continuous flooding } \\
\text { of fields during crop } \\
\text { cycle. }\end{array}$ & $\begin{array}{l}\text { llternate wetting and } \\
\text { drying. }\end{array}$ \\
\hline Weed control & $\begin{array}{l}\text { Hand weeding, or } \\
\text { herbicide use. }\end{array}$ & $\begin{array}{l}\text { Mechanical weeding, } \\
\text { aerating the soil. }\end{array}$ \\
\hline Fertilization & $\begin{array}{l}\text { Reliance on chemical } \\
\text { fertilizers. }\end{array}$ & $\begin{array}{l}\text { Organic matter as base } \\
\text { fertilization, } \\
\text { complemented if needed } \\
\text { with chemical fertilizer. }\end{array}$ \\
\hline \hline
\end{tabular}

Source: [13]

\section{METHODS}

The methods involved in this research encompasses the research location, literature review, comparative cost benefit analysis and research techniques.

\section{A. Location}

This study was being carried out at Kampung Klerek, an area under the District of Bachok in Kelantan. The said area is also part of the Kemubu Agriculture Development Authority granary jurisdiction. This location was selected due to its remoteness from the main roads with natural barriers like nipa palms and a river crossing the area. These physical characteristics, acting like a natural buffer, assist in the reduction of pollutants like air pollutant, which have the possibility of impacting negatively on the results of this study. Its remoteness together with its natural barriers help to deter natural threats like fowls, insects, parasites and other bio-pests. As this study focuses on the two farming methods of agroecological rice farming and conventional rice farming, a comparison would be made and thus, the extraneous factors need to be minimised or negated to make the findings have a high level of accuracy cum validity.

The two plots of land, of one acre each, were alongside one another with one plot dedicated to agroecological farming whereas the other is allocated for conventional farming. The same seeds, classified and branded as MRQ76, were used for both plots of land. Thus, variability in yield, due to same seed utilisation and physical proximity of both plots of land due to location specificity, were kept to the minimum.

\section{B. Literature Review}

Many countries including Malaysia provide government incentives for agriculture production, which also includes rice farming. These government incentives, mainly in the form of subsidies, are as highlighted in Table II. The provision of incentives has the dual purpose of addressing the socio-economic imbalance of rice farmers as well as in support of national food sovereign policy. The government incentives are basically to boost yield productivity and to reduce the cost of production for farmers. The national food sovereign policy is to reduce the dependence on imports and also its ability to feed the local populace in times of extenuating circumstances or emergencies.

TABLE II: GOVERNMENT INCENTIVES FOR PADDY FARMING IN MALAYSIA

\begin{tabular}{|c|c|c|c|}
\hline Policy & $\begin{array}{l}\text { Incentives and } \\
\text { Subsidies }\end{array}$ & Rationale & Rate \\
\hline \multirow[t]{3}{*}{$\begin{array}{l}\text { Agricultural } \\
\text { inputs }\end{array}$} & $\begin{array}{l}\text { Federal } \\
\text { Government's } \\
\text { Rice Fertiliser } \\
\text { Scheme }\end{array}$ & $\begin{array}{l}\text { To assist farmers in } \\
\text { reducing the costs of } \\
\text { production by } \\
\text { encouraging } \\
\text { fertiliser utilization } \\
\text { to improve yield. }\end{array}$ & $\begin{array}{l}12 \text { urea fertiliser } \\
\text { bags @20 kg/bag } \\
\text { per hectare and } 5 \\
\text { compound NPK } \\
\text { fertiliser bags @ } 20 \\
\text { kg/bag per hectare }\end{array}$ \\
\hline & $\begin{array}{l}\text { Rice Production } \\
\text { Incentive Scheme }\end{array}$ & $\begin{array}{l}\text { To aid farmers in the } \\
\text { reduction of the costs } \\
\text { of production via the } \\
\text { provision of } \\
\text { additional fertiliser. }\end{array}$ & $\begin{array}{l}5 \text { organic fertiliser } \\
\text { bags @ } 20 \mathrm{~kg} / \mathrm{bag} \\
\text { per hectare or } 6 \\
\text { bottles @ } 1 \\
\text { litre/bottle of folia } \\
\text { per hectare }\end{array}$ \\
\hline & $\begin{array}{l}\text { Legitimate Rice } \\
\text { Seeds Incentive }\end{array}$ & $\begin{array}{l}\text { To ensure farmers } \\
\text { use legitimate rice } \\
\text { seeds in improving } \\
\text { yield. }\end{array}$ & $\begin{array}{l}\text { Incentive of } \\
\text { RM1.03/kg } \\
\text { (RM20.60/bag) } \\
\text { was provided to } \\
\text { rice seed } \\
\text { producers for } \\
\text { supplying } \\
\text { legitimate paddy } \\
\text { seeds. }\end{array}$ \\
\hline Labour & $\begin{array}{l}\text { Rice Production } \\
\text { Incentive Scheme }\end{array}$ & $\begin{array}{l}\text { To aid farmers in the } \\
\text { reduction of the costs } \\
\text { of production via the } \\
\text { provision of } \\
\text { ploughing } \\
\text { assistance. }\end{array}$ & $\begin{array}{l}\text { Incentive of } \\
\text { RM240 per } \\
\text { hectare in } \\
\text { ploughing aid. }\end{array}$ \\
\hline Productivity & $\begin{array}{l}\text { Yield } \\
\text { Improvement } \\
\text { Incentive }\end{array}$ & $\begin{array}{l}\text { To promote yield } \\
\text { improvement on a } \\
\text { seasonal basis, with a } \\
\text { minimum } 1 \% \\
\text { seasonal yield } \\
\text { improvement as a } \\
\text { qualifier. }\end{array}$ & $\begin{array}{l}\text { Incentive of } \\
\text { RM650 per } \\
\text { additional metric } \\
\text { tonne for the } \\
\text { current season } \\
\text { vis-a-vis the } \\
\text { previous season. }\end{array}$ \\
\hline \multirow[t]{2}{*}{ Pricing } & $\begin{array}{l}\text { Minimum } \\
\text { Guaranteed Price }\end{array}$ & $\begin{array}{l}\text { To ensure farmers } \\
\text { receive the minimum } \\
\text { profit from the sale } \\
\text { of rice }\end{array}$ & $\begin{array}{l}\text { Minimum price of } \\
\text { RM1,200 per } \\
\text { metric tonne as } \\
\text { from } 2014 \text {, }\end{array}$ \\
\hline & $\begin{array}{l}\text { Rice Price Subsidy } \\
\text { Scheme }\end{array}$ & $\begin{array}{l}\text { To increase the } \\
\text { revenue of farmers } \\
\text { and also to ensure a } \\
\text { sustained price level } \\
\text { in the market for } \\
\text { consumers }\end{array}$ & $\begin{array}{l}\text { RM300 per metric } \\
\text { tonne as from } \\
2016 .\end{array}$ \\
\hline
\end{tabular}

Source: [14]

However, a prime problem in the provision of government incentives is the issue of stagnant productivity despite the escalating amount of farm subsidies [14]. This does not help in addressing the issue of socio-economic imbalance and poverty amongst the rice farmers.

Mohd Fuad Mat Jali et al. [4] asserted that to maintain the 
high rice yield output has led to the increased use of pesticides on rice fields in Malaysia. Their research indicated that the utilisation of pesticides harmed the environment, plants, fishes, livestock and farmers. Another research by Zainalabidin Mohamed et al. [15] highlighted that the excessive utilisation of fertilisers, pesticides and herbicides to increase rice yield has also led to the rice produce being contaminated with chemical residues. In addition, a study by Ali et al. [16] indicated that the overuse of pesticides in rice farming has an impact on human health and the environment. The findings revealed that the overuse of pesticides lead to greater expenditure on health care. Gianessi [17] indicated that rice production in South-East Asia increased by approximately $40 \%$ from 2000 to 2013 whereas for South Asia, the increase is approximately $30 \%$. One of the significant contributing factors is the increasing use of pesticides. In the years to come, the further adoption of fungicides and herbicides are measures undertaken to increase production. Moreover, the adoption of new insecticide products will help improve insect management, thus aiding productivity gains.

Uphoff (2002) [18] has argued that the 'mechanical' paradigms of conventional agriculture entail the process with inputs directly leading to outputs by adopting a fixed formula with linear and proportional relationships, thus, requiring a continuous flow of inputs. On the other hand, agroecology, recognises the inherently biological nature of agriculture with characteristics like less predictability, seldom in proportionality and often self-reproductivity. Thus, there is this intimate link between biological self-sustaining system and social capital. As such, sustainability draws attention to the co-evolution of both the ecological and social dimensions. Likewise, Pretty (2007) [19] also argued that despite the great progress in agriculture productivity for the past half-century would not remain linear in the future. New approaches that integrate biological and ecological processes in food production, the minimisation of non-renewable inputs that cause harm to the environment, and also the health of the farmers and consumers, the productive use of the knowledge and skills of farmers by substituting human capital for costly external inputs and also the productive use of people's collective capacities in working to solve common agricultural and natural resource problems like pest, watershed, irrigation, forest and credit management. Nicholls and Altieri (2017) [20] highlighted that the adoption of agroecological approaches enhanced the resilience of small farmers. Many studies have revealed that the adoption of agroecological practices by small farmers helped in coping with, and even preparing for climate change. By embracing farm biodiversity, soil cover and by enhancing soil organic matter, agroecological farmers are able to minimise crop failure under extreme climatic events.

The root causes of hunger, poverty and inequality can be addressed by agroecology through the transformation of the food and agriculture systems and the building of a resilient livelihood via a holistic approach that balances the three dimensions of environmental, economic and social sustainability. These three dimensions or pillars were explicitly embedded in the United Nation's Sustainable Development Goals. As such, agroecological rice farming is compatible with SRI and organic farming. The agroecological rice farming practices in Malaysia is based on the System of Rice Intensification (SRI). Malaysia has adopted the four main interacting principles of SRI methodology [13].

- Establishing plants early and quickly, to favour healthy and vigorous root and vegetative plant growth.

- Maintaining low plant density to allow optimal development of each individual plant and to minimize competitions between plants for nutrients, water and sunlight.

- Enriching soils with organic matter to improve nutrient and water holding capacity, increase microbial life in the soil, and to provide a good substrate for roots to grow and develop.

- Reducing and controlling the application of water, providing only as much water as necessary for optimal plant development and to favour aerobic soil conditions.

The farming practices of SRI optimise the use of in-situ local resources to lessen the dependence on external inputs. Seed utilisation is reduced via transplanting and not through the broadcasting method. Chemical fertilisers are substituted with organic fertilisers that are made from in-situ organic matters. These measures amongst others contribute to significant savings and thus leading to lower production cost.

According to Thawait et al. (2014) [21], SRI cultivation system will help to improve productivity due to a host of factors that include disease and pest reduction. The farmers are encouraged to use non-chemical methods in pest management until and unless the damage crosses the threshold limit.

A participant at the Consumers' Association of Penang (Malaysia) Go Natural fair who has adopted the SRI method indicated that rice yield has gone up by $100 \%$ [22]. Amongst her practices that are consistent with SRI are treated water that are free of chemical residues to enhance the growth of bacteria, insects, fish and microorganisms that ultimately will enrich the soil and water. Pests, especially Padi Fly (Leptocorisa spp) are managed by the utilisation of own-concocted natural pest repellents and also with the help of the natural food chain. For fertilisers, only animal and vegetable waste products are developed and converted into organic fertilisers at the field.

Luo (2018) [23] has outlined eight methods that have been adopted in relation to agroecological rice production in China. Some of these methods are a co-culture system, like rice-fish co-culture, rice-frog co-culture and rice-duck co-culture. The rice-duck co-culture system is a traditional form of agriculture in China. This form of co-culture system has been adopted in many Asian countries, including Malaysia. It focuses on synergistic interactions that establishes a biological pest control method in producing organic rice and duck.

\section{Comparative Cost-Benefit Analysis}

Comparative Cost-Benefit Analysis (CCBA) has the main purpose of determining which rice farming option is the better option. It also allows an in-depth analysis and evaluation of the differences of a particular benefit or cost and also the differences across the various types of benefits 
and costs accrued. In addition, it only encompasses three seasons, which is approximately within 12-calender months. CCBA is appropriate as the amount of capital expenditure and expenses are accrued within 12-calender months that is on a short time scale. The amount of capital expenditure is relatively small and thus can be expensed within the study period.

Three possible scenarios exist in the decision-making process in determining which is the better alternative. The first scenario is when both farming methods enjoy a Net Benefit situation with benefits greater than costs. In this context, the better alternative is the alternative with a higher net benefit. The second scenario is when one farming alternative enjoys a net benefit and the other suffering from a net loss and thus, the alternative with a net benefit is the better alternative. The third scenario is when both farming alternatives suffer from net loss with costs greater than benefits and thus, the better alternative is the alternative with a lower net loss.

The CCBA adopted in this evaluation only takes into consideration direct benefits and direct costs. This caveat focuses solely on the revenue and cost of production streams for the purpose of monetisation. Indirect benefits and indirect costs are precluded due to its complexity and variability in estimation. An example of indirect benefit like the provision of environmental services by a river is difficult to compute and is open to argument. Family labour provided by the wife and off-springs, volunteerism and mutual assistance (gotong royong) are also precluded due to the difficulty in imputing indirect labour cost.

\section{Research Techniques}

Three research techniques namely key informant interview, financial data analysis via Comparative Cost-Benefit Analysis and participant observation are employed in this study. The in-depth, semi-structured key informant interview method was focused on the farmer who was managing the along side of one acre each of agroecological rice farming and conventional rice farming respectively. A semi-structured questionnaire was used to provide the context for the financial data. For financial data analysis, the financial inputs were also obtained from the said key informant. The financial data were obtained for three seasons, namely the first season from July to November 2018, the second season from January to May 2019 and finally the third season from June to October 2019. Participant observation was also used during the field visits to gain a better understanding of the context and the situational factors in this research.

\section{RESULTS AND DISCUSSION}

The results (as indicated in a summarised format in Table III) and discussions will be based on firstly, the revenue schedule, followed by the cost of production schedule and finally net benefit. Thus, a conclusion can be drawn on which is the better farming alternative and also the ramifications on the environment and provision of government incentives.

TABLE III: COSTS AND BENEFITS OF AGROECOLOGICAL PADDY FARMING VERSUS CONVENTIONAL PADDY FARMING

\begin{tabular}{|c|c|c|c|c|c|c|}
\hline \multirow{2}{*}{$\begin{array}{l}\text { METHOD } \\
\text { HARVESTING PHASES }\end{array}$} & \multicolumn{3}{|c|}{ AGRO-ECOLOGY } & \multicolumn{3}{|c|}{ CONVENTIONAL AGRICULTURE } \\
\hline & $\begin{array}{l}\text { FIRST } \\
\text { SEASON } \\
\text { (JULY - NOV } \\
2018)\end{array}$ & $\begin{array}{l}\text { SECOND } \\
\text { SEASON } \\
\text { (JAN - MAY } \\
2019 \text { ) }\end{array}$ & $\begin{array}{l}\text { THIRD } \\
\text { SEASON } \\
\text { (JUNE - OCT } \\
2019)\end{array}$ & $\begin{array}{l}\text { FIRST } \\
\text { SEASON } \\
\text { (JULY - NOV } \\
2018)\end{array}$ & $\begin{array}{l}\text { SECOND } \\
\text { SEASON } \\
(\text { JAN - MAY } \\
2019)\end{array}$ & $\begin{array}{l}\text { THIRD } \\
\text { SEASON } \\
\text { (JULY - NOV } \\
2019 \text { ) }\end{array}$ \\
\hline $\begin{array}{l}\text { YIELD : METRIC TONNE } \\
\text { (MT)/ACRE }\end{array}$ & $3 \mathrm{MT}$ & $4 \mathrm{MT}$ & $3.5 \mathrm{MT}$ & $2.5 \mathrm{MT}$ & $3 \mathrm{MT}$ & $2.5 \mathrm{MT}$ \\
\hline PRICE OF RICE PER MT & RM1,560 & RM1,560 & RM1,560 & RM1,560 & RM 1,560 & RM1,560 \\
\hline RICE REVENUE & RM4,680 & RM6,240 & RM5,460 & RM3,900 & RM4,680 & RM3,900 \\
\hline GOVERNMENT ASSISTANCE & - & - & - & RM440 & RM440 & RM440 \\
\hline REVENUE & RM4,680 & R 6,240 & RM5,460 & RM4,780 & RM5,120 & RM4,340 \\
\hline $\begin{array}{l}\text { TOTAL REVENUE }\left(1^{\text {st }} \text { SEASON }+2^{\text {nd }}\right. \\
\left.\text { SEASON }+3^{\text {rd }} \text { SEASON }\right)\end{array}$ & RM16,380 & & & RM14,240 & & \\
\hline \multicolumn{7}{|c|}{ COST OF PRODUCTION SCHEDULE } \\
\hline LAND RENTAL COST & RM200 & RM200 & RM200 & RM200 & RM200 & RM200 \\
\hline LABOUR COST & RM185 & RM135 & RM135 & RM250 & RM250 & RM250 \\
\hline $\begin{array}{l}\text { SEED } \\
\text { ANCILLARY COST }\end{array}$ & RM61.4 & RM1.4 & RM1.4 & RM70 & RM70 & RM70 \\
\hline PESTICIDE COST & - & - & - & RM810 & RM810 & RM810 \\
\hline FERTILISER COST & RM484 & RM456 & RM456 & RM171 & RM171 & RM171 \\
\hline $\begin{array}{l}\text { FUEL \& ANCILLARY COST FOR } \\
\text { MACHINERY }\end{array}$ & RM198.30 & RM143.80 & RM143.80 & RM225.10 & RM225.10 & RM225.10 \\
\hline OPERATIONAL COST & RM1,128.70 & RM936.20 & RM936.20 & RM1,726.10 & RM1,726.10 & RM1,726.10 \\
\hline $\begin{array}{l}\text { TOTAL OPERATIONAL COST } \\
\left(1^{\text {st }} \text { SEASON }+2^{\text {nd }} \text { SEASON }+3^{\text {rd }}\right. \\
\text { SEASON })\end{array}$ & RM3,001.10 & & & RM5,178.3 & & \\
\hline $\begin{array}{l}l \\
\text { NET BENEFIT(LOSS)= } \\
\text { GRAND REVENUE } \quad-\text { GRAND } \\
\text { OPERATIONAL COST }\end{array}$ & RM13,378.90 & & & RM9,061.70 & & \\
\hline
\end{tabular}


For the revenue stream, agroecological rice farming had a total yield of 10.5 metric tonnes for the three seasons. This amounted to RM16,380 with an ex-mill price of RM1,560 per metric tonne. However, the revenue for conventional rice farming was RM14,240 based on a yield of eight metric tonnes with the same ex-mill price. This shows that agroecological rice farming has a higher yield compared to conventional rice farming. This is significant as the farmer, despite a lack of experience in agroecological rice farming, is able to produce a higher yield in his maiden attempt. It can be projected that by undergoing the learning and experience curve over time, yield productivity can be higher. This is in comparison with the long involvement of the farmer with conventional rice farming. Another noteworthy point was the higher ex-mill price of RM1,560 per metric tonne for MRQ76 as compared to the Guaranteed Minimum Price of RM1,200. MRQ76, a fragrant rice variety, is able to command a premium in the market and thus, the government need not provide subsidy provision under the Guaranteed Minimum Price incentive.

The cost of production schedule consisted of 1) land rental cost, 2) labour cost, 3) seed utilisation and ancillary cost, 4) pesticide cost, 5) fertiliser cost, 6) fuel and ancillary cost for machinery which consist of 6.1) fuel cost for niplo rotary tiller, 6.2) fuel and ancillary cost for power sprayer, 6.3) fuel and ancillary cost for rice blower, 6.4) fuel and ancillary cost for fertiliser blower, 6.5) fuel cost for rice harvester and 6.6) fuel cost for hand tractor.

For land rental cost, both farming alternatives bore the same rental cost of RM200 per acre per season. Both plots of land of size 1 acre each, were rented by the farmer. Thus, land rental cost had no impact on cost differential.

The labour cost for agroecological rice farming was marginally lower at RM455 as compared to RM750 for conventional rice farming. This was due in part to lower tillage labour cost for agroecological rice farming as tillage and soil levelling was required for only the first season whereas for conventional rice farming, every season requires tillage and soil levelling. Seeding via the broadcast method was applied in conventional rice farming whereas manual transplanting was done for agroecological rice farming. Broadcast seeding had a higher cost of RM50 per season as compared to manual transplanting of RM35 per season. For fertilising labour cost, both farm alternatives bore the same cost. However, for pesticide labour application, this cost was borne only for conventional rice farming as agroecological rice farming does not utilise synthetic pesticide. At this juncture, the farmer has yet to develop in-situ bio-pesticides or antimicrobial pesticides. In addition, natural pest control methods like rearing ducks has yet to be introduced. This is mainly due to the lack of experience in agroecological farming practices as this is his maiden effort. Finally, the harvesting labour cost for both farming alternatives were the same. Thus, the lower labour cost for agroecological rice farming was due mainly to lower labour cost for tillage and soil levelling, lower seeding cost as well as the lack of need for pesticide application.

For seed utilisation and ancillary cost, agroecological rice farming had a lower cost as compared to conventional rice farming. This was due to different farming practices. In agroecological rice farming, the seeds are germinated in trays and the seedlings are manually transplanted on the field. Thus, there is no wastage of seeds or seedlings. However, for conventional rice farming, the broadcasting method of sowing leads to wastage. In addition, the purchase of trays, a one-time expense, for the purpose of germinating the seeds can be reused for the following seasons. Thus, precision transplanting as adopted by agroecological rice farming has led to cost saving of RM145.80, despite the one-time expense for trays. This amount was relatively marginal.

Conventional rice farming is highly dependent on synthetic pesticide which is of industrial origin. Diametrically opposite is agroecological rice farming which employs natural pesticides like bio-pesticides or antimicrobial pesticides and natural pest control methods like rearing ducks on the farm. The high reliance on synthetic pesticides resulted in a high pesticide cost differential of RM2,430 even though it was acknowledged that no natural-based pesticides or natural pest control methods were used as this was a maiden agroecological rice farming attempt. However, the mutually beneficial duck-rice farming co-culture option or other natural pest control methods have yet to be exploited by this farmer. These options may be low cost options in managing pests and at the same time can help generate potential earnings like duck eggs and meat.

For fertiliser cost, agroecological rice farming incurred a higher cost as organic fertilisers were procured. Organic fertilisers are much more expensive as compared to the synthetic variants. As the farmer has yet to engage in the preparation of manure and compost as organic fertilisers, all the organic fertilisers' requirements were purchased from the market. If the farmer were to engage in the formulation, development and application of organic fertilisers, the fertiliser cost can be progressively reduced. However, the Federal Government's Rice Fertiliser Scheme and the Production Rice incentives are of insufficient amount for conventional rice farming and need to be supplemented by additional purchase. Thus, the agroecological rice farming alternative had to bear the higher cost differential of RM883 due mainly to the purchase of organic fertilisers.

Agroecological rice farming had a lower fuel cum ancillary cost for machinery as compared to conventional rice farming. The contribution to lower cost was due in part to the lower fuel and ancillary cost for operating the niplo rotary tiller. As mentioned earlier, tilling and soil levelling was required for the opening season for agroecological rice farming whereas it was required for all three seasons for conventional rice farming. Other contributory factors were the fuel and ancillary cost for the motorised power-sprayer and mist blower for the application of synthetic pesticide for conventional rice farming. As in this circumstance, the farmer did not apply any pesticide at all for the agroecological farming alternative, thus contributing to lower fuel cum ancillary cost for machinery. However, both farming methods needed to operate the fertiliser blower, rice harvester and hand tractor and as such, the cost quantum for the fertiliser blower was higher for agroecological farming as more rounds were required whereas for rice harvester and hand tractor, the quantum for these two were the same. Therefore, the lower fuel cum ancillary cost for machinery 
for agroecological rice farming was attributed to the lower tilling and soil levelling cost and also the non-necessity for the application of synthetic pesticides.

On an overall basis, the cost of production for agroecological rice farming was lower as opposed to conventional rice farming. The contributory factors were lower labour cost, lower seed utilisation and ancillary cost, zero cost for synthetic fertilisers and lower fuel and ancillary cost for machinery in spite of higher organic fertiliser cost. The lower cost differential for agroecological rice farming amounted to RM2,177.20.

Both farming methods attained a net benefit situation where the revenue was greater than the cost of production. Nevertheless, agroecological rice farming had a higher net benefit with a differential of RM5,357.20 as compared to conventional rice farming. The contributory factors for a higher net benefit were a higher rice yield with resultant higher revenue in tandem with lower cost of production. This also carries the implication that a more environmentally friendly approach is also aligned with a higher profitability alternative. The results also support the arguments put forth by Uphoff which recognises the inherently biological nature of agriculture and also the intimate link between biological self-sustaining system with social or human capital. The new approaches as advocated by Pretty via the minimisation of non-renewable inputs with the substitution of organic fertilisers, intensive use of human capital for seeding, lower tillage and the non-application of synthetic pesticides have led to a higher net benefit for the SRI agroecological farming alternative. The application of organic fertilisers has likely enhanced the soil organic matter as mentioned by Nicholls and Altieri in relation to plant growth and soil productivity.

\section{CONCLUSION}

Both conventional rice farming and agroecological rice farming alternatives are viable options. However, in conclusion, agroecological rice farming is a much more viable alternative as the net benefits are higher. It is even more so taking into effect on a long-term basis as the cost of production can be lowered with the learning and experience effect. The higher yield and the resultant higher revenue for agroecological rice farming has the potential to be increased if the full array of SRI farming practices were adopted. A longitudinal research in this area would be interesting as it can help to ascertain the determinants.

The cost of production for agroecological rice farming is lower than conventional rice farming and has the potential to be even lower. The contributory factors are lesser wastage of resources like seed utilisation, lower labour cost and lower fuel cum ancillary cost for machinery. As this is the farmer's maiden effort in agroecological rice farming, high organic fertiliser cost is incurred through purchases. However, with the passage of time, the learning and experience effect can be brought to bear to bring down fertiliser cost via the development and application of organic fertilisers. For pest management, the development and application of bio-pesticides, antimicrobial pesticides and other forms of natural pest control methods like rice-duck co-culture system can help to lower cost even further. The rice-duck co-culture system can even help to boost income via the sales of duck eggs, live poultry and duck meat. All these measures, if implemented are in sync with good environmental practices.

\section{CONFLICT OF INTEREST}

The authors declare no conflict of interest.

\section{AUTHOR CONTRIBUTIONS}

Er, A.C. is the lead and corresponding author of this article. She conducted the research, did the comparative cost-benefit analysis and wrote the article. Habibah Ahmad is co-researcher of this research project. Azima Abdul Manaf assisted in the literature review.

\section{ACKNOWLEDGMENT}

The authors would like to express their deepest gratitude to Universiti Kebangsaan Malaysia Grand Challenge Grant DCP-2017-004/4 under the leadership of Prof. Dr. Er Ah Choy for the funding of this research.

\section{REFERENCES}

[1] A. Ramli, "Potensi padi spesialti dalam pembangunan ekonomi pesawah di Malaysia," Konvensyen Padi Kebangsaan, Malaysia: Muda Agricultural Development Authority (MADA), 2019.

[2] S. C. Omar, A. Shaharudin, and S. A. Tumin, The Status of the Paddy and Rice Industry in Malaysia, Malaysia: Khazanah Research Institute, 2019.

[3] C. S. Chan, I. M. Zainal, and A. D. Hassan, "Agricultural machinery and mechanization development in Malaysia," Regional Forum 2013 , 2013.

[4] M. F. M. Jali, J. A. Besar, H. Ahmad, and H. Jusoh, "The impact of pesticides on paddy farmers and ecosystem," Advances in Natural and Applied Sciences, vol. 6, no. 1, pp. 65-7, 2012.

[5] M. I. Ahmad, N. A. Ahmad, S. A. Muhammad, and N. Esa, "A survey on use, hazards and potential risks of rice farming pesticides in Permatang Keriang, Pulau Pinang (Malaysia),” International Journal of Scientific and Research Publications, vol. 4, no. 10, pp. 1-11, 2014.

[6] Mu. M. Rahaman, K. S. Islam, and M. Jahan, "Rice farmers" knowledge of the risks of pesticide use in Bangladesh," Journal of Health and Pollution, vol. 8, no. 20, pp. 1-9, 2018.

[7] B. Hou and L. Wu, "Safety impact and farmer awareness of pesticide residues," Food and Agricultural Immunology, vol. 21, no. 3, pp. 191-200, 2010.

[8] B. Ndayambaje, H. Amuguni, J. Coffin-Schmitt, N. Sibo, M. Ntawubizi, and E. VanWormer, "Pesticide application practices and knowledge among small-scale local rice growers and communities in Rwanda: A cross-sectional study," International Journal of Environmental Research and Public Health, vol. 16, no. 4770, pp. 1-11, 2019.

[9] United Nations. (2015). Transforming our World: The 2030 Agenda for Sustainable Development (A/RES/70/1). [Online]. Available: sustainabldevelopment.un.org

[10] D. Nierenberg. (2014). Five ways System of the Rice Intensification (SRI) practices and ideas can help "feed the world". [Online]. Available: https://foodtank.com-2014/01,

[11] N. Uphoff and F. B. Dazzo, "Making rice production more environmentally-friendly," Environments, vol. 3, no. 12, pp. 1-7, 2016.

[12] T. Chapagain and E. Yamaji, "Assessment of system of rice intensification (SRI) and conventional practices under organic and inorganic management in Japan," Rice Science, vol. 18, no. 4, pp. 311-320, 2011

[13] SRI-RICE. (2015). SRI International Network and Resources Centre: Frequently Asked Questions (FAQs). [Online]. Available: sri.ciifad.cornell.edu/aboutssri/FAQs1.html\#mainenvironmental

[14] F. Kari, "Evaluation of agricultural subsidies and the welfare of farmers," Malaysia Agricultural Subsidies Report 2018, IDEAS, Kuala Lumpur, 2018.

[15] Z. Mohamed, R. Terano, J. Sharifuddin, and G. Rezai, "Determinants of paddy farmer's unsustainability farm practices," Agriculture and Agricultural Science Procedia, vol. 9, pp. 191-196, 2016. 
[16] J. Ali, N. Yusof, and F. A. Aziz, "Factors influencing farmer's perceptions and behaviour toward pesticide use in Malaysia," International Journal of Social Economics, vol. 45, no. 5, pp. 776-792, 2018.

[17] L. P. Gianessi, "The increasing importance of herbicides in worldwide crop production," Pest Management Science, vol. 69, no. 10, pp. 1099-1105, 2013.

[18] N. Uphoff, Agroecological Innovations, Increasing Food Production with Participatory Development, London, UK.: Earthscan, 2002.

[19] J. Pretty, "Agricultural sustainability: Concepts, principles and evidence," vol. 363, 2007.

[20] C. I. Nicholls and M. Altieri, Perspectives: Agroecological Approaches to Enhance Resilience among Small Farmers, ILEIA, 2017.

[21] D. Thawait, S. Kar, and A. K. Pater, "Disease and pest management in system of rice intensification for sustaining crop health and production," presented at 5th International Conference on Agriculture and Horticulture, Hyderabad International Convention Centre, India, October 27-29, 2014

[22] Consumer Association of Penang. (2011). Organic SRI rice: Higher yields and safe for us and the environment. [Online]. Available: https//consumer.org.my/organic-sri-rice-higher-yields-and-safe-for-us -and-the-environment/

[23] S. Luo, Agroecological Rice Production in China: Restoring Biological Interactions, Food and Agriculture Organization of the United Nations, Rome, 2018.

[24] Fieldwork 2018-2019: Research Project DCP-2017-004/4 under the Leadership of Prof. Dr. Er Ah Choy.

Copyright $\odot 2021$ by the authors. This is an open access article distributed under the Creative Commons Attribution License which permits unrestricted use, distribution, and reproduction in any medium, provided the original work is properly cited (CC BY 4.0).

Er Ah Choy has graduated with a doctoral degree from the Wageningen University, The Netherlands in 2007. She is a professor of environmental science in the Faculty of Social Sciences and Humanities, Universiti Kebangsaan Malaysia. Currently, she also holds the post of chairperson, Centre for Research in Development, Social and Environment. Prof. Dr. Er's research outputs are published extensively in international and local journals in the areas of environmental policy and management, specifically in relation to the oil palm and palm oil chain and also the ecotourism sector. Her published articles are also found in High Impact Factor Journals. In addition, she also has contributed a number of chapters with renowned publishers.

Habibah Ahmad obtained her PhD from Universiti Kebangsaan Malaysia in 2007. She is an associate professor in the Centre for Research in Development, Social and Environment, Faculty of Social Sciences and Humanities, Universiti Kebangsaan Malaysia. Currently, she is also a coordinator at UKM-Centre for Entrepreneurship and SMEs Development (CESMED). Her areas of expertise are in tourism development and family tourism with her research encompassing tourism development, homestays and also family-friendly beach tourism.

Azima Abdul Manaf obtained her PhD. in the field of land management from Universiti Teknologi Malaysia in 2016. She is an associate professor in the Centre for Research in Development, Social and Environment, Faculty of Social Sciences and Humanities, Universiti Kebangsaan Malaysia. Her areas of expertise encompass land development and administration, land and community development and development project management. 